\title{
РАК ЩИТОВИДНОЙ ЖЕЛЕЗЫ ПОСЛЕ ЧЕРНОБЫЛЬСКОЙ КАТАСТРОФЫ И НОВЫЕ ВОЗМОЖНОСТИ СНИЖЕНИЯ ПОВРЕЖДЕНИЙ ВОЗВРАТНЫХ ГОРТАННЫХ НЕРВОВ У ВЗРОСЛЫХ, ДЕТЕЙ И ПОДРОСТКОВ
}

\author{
Романчишен А.Ф., Вабалайте К.В., Демидчик Ю.Е.
}

Кафедра госпитальной хирургии Санкт-Петербургского государственного педиатрического медичинского университета. Санкт-Петербургский центр эндокринной хирургии и онкологии

Актуальность изучения этиопатогенеза, профилактики и лечения больных раком щитовидной железы (РЩЖ) несомненна.

МАТЕРИАЛЫ И МЕТОДЫ: для вЫяснения изменений в эпидемиологии, патогенезе, клинических проявлениях мы сравнили опыт лечения 1942 пациентов РЩЖ детского и подросткового возраста в различных клиниках России, Белоруссии и Украины (Санкт-Петербург, Челябинск, Архангельска, Минск и Киев) до и после Чернобыльской катастрофы.

РЕЗУЛЬТАТЫ: заболеваемость РЩЖ у детей до 14 лет в Беларуси выросла с 0,3 на миллион детского населения (МДН) в период 1981-1985 гг. до 30,6 в 1991-1994 гг. В Гомельской области она увеличилась в 200 раз. Наибольшая заболеваемость детей выявлена в возрасте до 4 лет (1982-1986 гг.). На Украине она выросла с 0,4 до 4 МДН (в 10 раз). В пяти северных областях Украины, наиболее загрязненных радиоактивным йодом, в 1992-1994 гг. заболеваемость достигала 11,5 на МДН (в 28 раз выше исходной). Этот показатель в Санкт-Петербурге (СПб) в период до 1985 г. составлял 0,2. Но в 1994-1995 гг. он вырос до 0,7 - для мальчиков и 1,0 - для девочек. То есть, почти достиг того же уровня, что и в радиозагрязненных регионах Украины. В 2000-х этот показатель постепенно уменьшился до исходного уровня. Однако начала расти заболеваемость РЩЖ подростков, а в дальнейшем - молодых людей в возрасте до 35 лет.

Изучение 1942 наблюдений показало, что РЩЖ у детей протекал очень агрессивно, особенно радиоиндуцированный и "спорадический": в 62,2\% выявлены регионарные метастазы, в 18,2\% - экстратиреоидное распространение, в 19,9\% - многофокусный рост, в 12,2\% выявлялись до- и послеоперационные отдаленные метастазы, в 1,3\% наступила смерть от прогрессирования опухоли. В конце 90-х годов сроки верификации рака ЩЖ у детей колебались между 6 и 12 месяцами. К 2010-м годам этот период снизился до 4-7 месяцам. Длительные сроки диагностики РЩЖ у детей объяснялись тем, что около четверти детей получали консервативное лечение тироксином, йодидами, противовоспалительную физиотерапию на шею, вплоть до противотуберкулезных препаратов в связи с «милиарным туберкулезом легких». Средний срок диагностики РЩЖ у больных, не получавших лечение, за 8 лет сократился с 8 до 2,4 месяца, благодаря просветительской работе. Реализовалась необходимость в тиреоидэктомии с центральной лимфаденэктомией для профилактики рецидивов опухоли, и обоснованной терапии радиойодом. В СПб Центре Эндокринной Хирургии и Онкологии с 2001 г. внедрен в практику интраоперационный мониторинг возвратных гортанных нервов (ИОМ ВГН) у взрослых и детей что облегчило сохранение функции нервов, сократило продолжительность операций, уменьшило психоэмоциональное напряжение хирурга. Наш опыт использования мониторинга ВГН с 2001 года составляет более 1700 операций. Снижена частот повреждений ВГН более чем в 6 раз в период с 2001 по 2015 гг. Теперь мы широко ее используем у детей и подростков в соответствие с распоряжение Министерства здравоохранения России.

Повторные операции предпринимались ввиду послеоперационных метастазов (9.2\%), рецидивов опухоли (3.1\%). Операцией выбора при РЩЖ у детей теперь является тиреоидэктомия и центральная лимфаденэктомия. Исключение может быть сделано лишь при T1NOMO. Показатели 10 и 20 летней выживаемости детей превысили 95\%.

ВЫВОдЫ: заболеваемость детского населения Санкт-Петербурга изменилась аналогично таковой в Беларуси и Украине после Чернобыльской катастрофы. Клиническое течение радиоиндуцированного РЩЖ особенно агрессивное. Адекватное хирургическое лечение, при необходимости дополненное радиойодтерапией, обеспечивает выздоровление более $95 \%$ пациентов. 